\title{
PENGENDALIAN CROCIDOLOMIA PAVONANA PADA TANAMAN KUBIS SECARA TERPADU
}

\section{INTEGRATED CONTROL OF CROIDOLOMIA PAVONANA ON CABBAGE}

\author{
Frangky J. Paat * dan Redsway T. D. Maramis**) \\ ${ }^{*}$ Dosen Program Studi Agroekoteknologi, Fakultas Pertanian Unsrat Manado, 95115 \\ *) Dosen Program Studi Proteksi Tanaman, Fakultas Pertanian Unsrat Manado, 95115
}

\begin{abstract}
Research on the integrated control of Crocidolomia pavonana on cabbage aims to test various cabbage cultivation techniques, namely the use of organic fertilizers, botanical insecticides, and multiple croping. This research was conducted in Paslaten Sub-District, Tomohon City, from January 2011 to January 2012. The parameters observed included the percentage of attacks, cabbage production, profit analysis of organic and non- organic cultivation, measurement of climate parameters, analysis of total soil $\mathrm{N}$ content, total $\mathrm{N}$ content of fertilizer organic foliage and chicken manure. This experiment used a randomized block design (RBD) with orthogonal contrast with eleven (11) treatments and four (4) replications. The results showed that the highest attack percentage at 6 mst was found in mitraflora $+B$. asiatica fertilizer treatment $12.5 \%$ chicken manure $+B$. asiatica $7.14 \%$, farmer habit patterns $5.36 \%$, and campus organic fertilizer treatment $+B$ asiatica $1.79 \%$. The highest percentage of attacks at 8 mst was found in the treatment of mitraflora + B. asiatica fertilizer $37.5 \%$, chicken manure + B. asiatica $26.79 \%$, campus organic fertilizer + B. asiatica $16.07 \%$, farmers' habit patterns $7.14 \%$. The highest attack percentage at 10 mst was found in mitraflora $+B$. asiatica fertilizer treatment $21.43 \%$, farmer habit pattern treatment $16.07 \%$, chicken manure $+B$. asiatica $12.5 \%$, campus organic fertilizer $+B$. asiatica $10,71 \%$. The highest cabbage production was produced by the treatment of farmers' habit patterns, namely $42.8 \mathrm{~kg} /$ plot, followed by the treatment of campus organic fertilizer $+B$. asiatica with a production rate of $34.6 \mathrm{~kg} /$ plot, treatment of chicken manure $+B$. asiatica 29.5 $\mathrm{kg} /$ plot, fertilizer treatment mitraflora + B. asiatica $27.8 \mathrm{~kg} /$ plot.
\end{abstract}

Keywords: multiple croping, cabbage, C. pavonana

\begin{abstract}
ABSTRAK
Penelitian mengenai pengendalian Crocidolomia pavonana pada tanaman kubis secara terpadu bertujuan untuk menguji berbagai teknik budidaya tanaman kubis yaitu penggunaan pupuk organik, insektisida botanis, dan multiple croping. Penelitian ini dilaksanakan di Kelurahan Paslaten Kota Tomohon, pada bulan Januari 2011 sampai dengan Januari 2012. Parameter yang diamati meliputi persentase serangan, produksi kubis, analisis keuntungan budidaya organik dan non organik, pengukuran parameter iklim, analisis kandungan $\mathrm{N}$ total tanah, kandungan $\mathrm{N}$ total pupuk organic dedaunan dan pupuk kandang ayam. Percobaan ini menggunakan Rancangan Acak Kelompok (RAK) Kontras Ortogonal dengan sebelas (11) perlakuan dan empat (4) ulangan. Hasil penelitian menunjukkan bahwa persentase serangan tertinggi pada $6 \mathrm{mst}$ terdapat pada perlakuan pupuk mitraflora $+B$. asiatica $12,5 \%$ pupuk kandang ayam $+B$. asiatica $7,14 \%$, pola kebiasaan petani $5,36 \%$, dan perlakuan pupuk organik kampus $+B$. asiatica 1,79\%. Persentase serangan tertinggi pada 8 mst terdapat pada perlakuan pupuk mitraflora + B. asiatica $37,5 \%$, pupuk kandang ayam + B. asiatica $26,79 \%$, pupuk organik kampus + B. asiatica $16.07 \%$, pola kebiasaan petani $7.14 \%$. Persentase serangan tertinggi pada $10 \mathrm{mst}$ terdapat pada perlakuan pupuk mitraflora $+B$. asiatica $21,43 \%$, perlakuan pola kebiasaan petani $16,07 \%$, pupuk kandang ayam + B. asiatica $12,5 \%$, pupuk organik kampus + B. asiatica 10,71\%. Produksi kubis tertinggi dihasilkan oleh perlakuan pola kebiasaan petani yaitu $42,8 \mathrm{~kg} / \mathrm{petak}$, diikuti oleh perlakuan pupuk organik kampus + B. asiatica dengan angka produksi $34,6 \mathrm{~kg} /$ petak, perlakuan pupuk kandang ayam + B. asiatica 29,5 $\mathrm{kg} /$ petak, perlakuan pupuk mitraflora + B. asiatica $27,8 \mathrm{~kg} /$ petak.
\end{abstract}

Kata kunci: multiple croping, kubis, C. pavonana

Eugenia Volume 25 No. 1 Pebruari 2019 


\section{PENDAHULUAN}

Konsekuensi lingkungan dari penggunaan insektisida sintetik adalah hama-hama telah berkembang dan menjadi tahan terhadap berbagai formulasi insektisida. Terjadi resurjensi terhadap sejumlah formulasi insektisida sintetik membunuh musuh-musuh alami dan mahluk-mahluk bukan sasaran (Pelelau, 2019).

Komisi Uni Eropa mempublikasikan peraturan baru dan diadaptasikan dalam Regulasi Umum Uni Eropa tentang impor produk organik. Regulasi ini mewajibkan semua produk organik impor harus disertifikasi oleh lembaga atau otoritas inspeksi yang diakui oleh Komisi Uni Eropa. PHT adalah teknologi pengendalian hama yang pendekatan komprehensif berdasarkan prinsip-prinsip ekologi yang dalam keadaan lingkungan tertentu mengusahakan pengintegrasian berbagai taktik pengendalian yang kompatibel satu dengan yang lainnya sedemikian rupa sehingga populasi hama selalu berada dalam jumlah yang secara ekonomis tidak merugikan, mempertahankan kelestarian lingkungan dan menguntungkan bagi petani.

Tujuan Pengelolaan Hama Terpadu tidak hanya bertujuan pengendalian hama saja tetapi mempunyaitujuan komprehensif antara lain, yaitu: produksi pertanian tinggi, peningkatan kesejahteraan petani, memperhatikan populasi hama dalam keseimbangan. Tujuan lainnya adalah memperhatikan keanekaragaman hayati, pembatasan penggunaan insektisida sintetik, mengurangi resiko keracunan pada manusia dan hewan (Ooi, 1998).

Salah satu kendala teknis yang menjadi kendala produksi lokal dalam areal budidaya kubis adalah serangan hama C. pavonana. Berdasarkan hasil penelitian Wanta, dkk (1993) bahwa titik berat pengendalian hama tanaman Kubis di Provinsi Sulawesi Utara masih ditujukan pada pengendalian secara kimia. Pengendalian hama sayursayuran terutama Kubis di Provinsi Sulawesi Utara ternyata telah dilakukan para petani secara berlebihan baik dari segi dosis maupun jumlah perlakuan (Sembel, dkk., 1989). Penggunaan insektisida sintetik secara kontinu dan berulangulang oleh petani telah menimbulkan pencemaran lingkungan serta ketahanan hama terhadap insektisida sintetik itu sendiri, sehingga dalam kasus-kasus tertentu dapat menimbulkan ledakan populasi atau berkembangnya hama baru yang dulunya tidak berstatus hama.

Tujuan penelitian ini adalah untuk menguji komponen-komponen pendukung PHT dengan membandingkan perlakuan penggunaan komponen organik, insektisida botanis, dan multiple cropping dengan pola kebiasaan petani pada tanaman kubis. Hasil penelitian ini diharapkan menjadi landasan yang kuat untuk perencanaan dan pengembangan model atau teknologi pengendalian hama terpadu (PHT) sayuran kubis.

\section{BAHAN DAN METODE}

\section{Tempat dan Waktu Penelitian}

Penelitian lapangan di Kelurahan Paslaten Kota Tomohon. Waktu penelitian dilaksanakan dari bulan Januari 2011 sampai dengan Januari 2012.

\section{Bahan dan Alat}

Bahan yang digunakan adalah : benih Kubis varietas Grand @11, pupuk kandang ayam, pupuk organik "kampus" dicampur sekam padi yang siap pakai, larva uji $\mathrm{C}$. pavonana, aquades, larutan madu, tanah gembur, alkohol 70 $\%$, polybag.

Alat-alat yang digunakan antara lain meliputi : kantong plastik, mikroskop, termohygrometer, termometer, loupe, gunting pangkas, alat penghitung, baki plastik, kotak acrylic, timbangan digital, kotak plastik $(30 \times 20 \times 5 \mathrm{~cm})$, kotak penangkar serangga $(40 \times 40 \times 40) \mathrm{cm}$, tissue, botol kaca 3 $\mathrm{ml}$, stoples, kapas, kuas, gunting, kertas label, scooring board, buku, pulpen, kamera digital, handycamp, laptop dan alat bantu lainnya.

\section{Metode Penelitian}




\section{Persentase Serangan}

Penelitian ini meggunakan sistem multiple croping dan menggunakan metode rancangan acak kelompok ortogonal kontras dengan 11 perlakuan dan empat (4) ulanganyang terdiri dari 1 kontrol, 3 jenis pupuk organik, 6 tingkatan perlakuan tanaman sela, serta 1 perlakuan berdasarkan pola kebiasaan petani menggunakan insektisida sintetik dan pemupukan anorganik. Hal yang diamati adalah perkembangan dan populasi larva setelah dilakukan perlakuan ekstrak bahan tanaman. Pengamatan dilakukan setiap minggu setelah perlakuan. Mengamati persentase jumlah tanaman yang terserang pada setiap plot percobaan dan membandingkan pada kontrol. Persentase dihitung berdasarkan metode sensus, yaitu menghitung jumlah seluruh tanaman yang terserang dan tidak terserang di kali $100 \%$. Pengamatan tanaman dilakukan berdasarkan sistem sensus tiap tanaman uji.

\section{Produksi tanaman}

Pemanenan dilakukan dengan cara menimbang bobot krop kubis/10 tanaman contoh dan ubinan lima petak contoh yang diambil secara diagonal, masing-masing seluas $4 \mathrm{~m}^{2}$ (10 tanaman) dan dikonversikan per hektar (Anonim, 1995). Produksi dihitung berdasarkan penimbangan krop setiap tanaman disetiap petak percobaan. Interaksi antar plot percobaan dianalisis menggunakan Rancangan Acak Kelompok (RAK) Kontras Ortogonal. Melalui uji kontras dapat ditentukan derajat polinomial dari faktor utama.Untuk faktor interaksi, kontraskontras ortogonalnya ditentukan melalui kontras-kontras dari

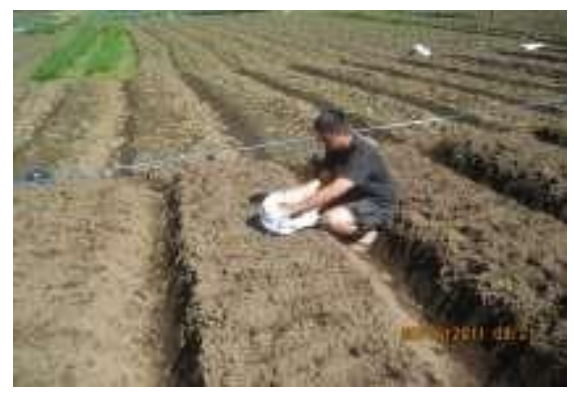

faktor utama.Banyaknya kontras ortogonal yang dapat dibentuk sebanyak perkalian antara banyaknya kontras ortogonal dari faktor ke 1 dengan faktor ke 2. Melalui uji kontras dapat ditentukan bentuk interaksi dan derajat dari polinomialnya.Dengan menggabungkan polinomial dari faktor utama dan faktor interaksi akan diperoleh pendekatan regresi polinomial orthogonal. Penentuan kontras-kontras ortogonal yang nyata baik untuk faktor utama maupun faktor interaksi sehingga dapat ditentukan bentuk umum dari pendekatan kontras ortogonalnya dengan menggunakan program SAS. Berdasarkan bentuk yang diperoleh pendekatan persamaan regresi polynomial dilakukan dengan program Minitab 16 (Mattjik dan Sumertajaya, 2002).

\section{Persiapan Lahan dan Pola Tanam Kubis}

Pengolahan tanah menggunakan traktor tangan (hand tractor). Derajat kemasaman (pH) tanah diukur dengan $\mathrm{pH}$ meter. Jika pH tanah kurang dari 5,5 digunakan kapur pertanian atau dolomit (2-4 ton/ha). Kapur disebar rata lalu dicangkul merata supaya $\mathrm{pH}$ tanah menjadi \pm 6.0 (Anonim, 1995). Lahan seluas $500 \mathrm{~m}^{2}$ dibagi dua, dibuat petak PHT $\left(250 \mathrm{~m}^{2}\right.$ ) dan Petak pola kebiasaan petani (non PHT 250 $\mathrm{m}^{2}$ ), luas bedengan $5 \times 1 \mathrm{~m}$ dibagi dalam 4 blok ulangan. Total 224 populasi tanaman kubis varietas @Grand 11.Jarak tanam $50 \times 50 \mathrm{~cm}$,jarak antar bedeng $50 \times 50 \mathrm{~cm}$, luas lahan $250 \mathrm{~m}^{2}$ dengan pola tanam sistem zigzag.Sebelum dan sesudah penanaman dilakukan analisis kandungan $\mathrm{N}$ total tanah, pengukuran kandungan $\mathrm{N}$ total pupuk kandang ayamdan pupuk organik dedaunan

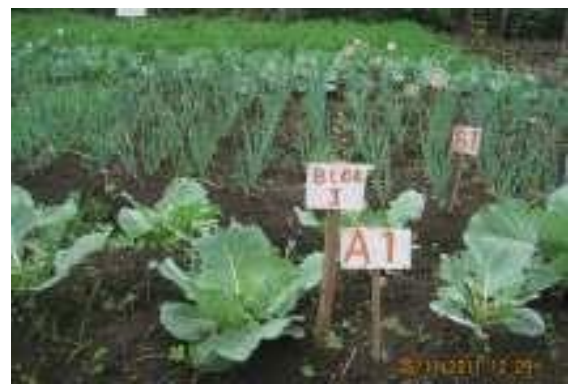

Figure 1. Land Processing, Application of Several Organic Fertilizer Treatments and Setting of Planting Patterns. 
Pemupukan pupuk kampus dan pupuk kandang berdasarkan kebiasaan petani yaitu satu genggamantangan/lubang tanam \pm 200 gram. Pemberian pupuk mitraflora dilaksanakan pada pagi hari berdasarkan petunjuk penggunaan pupuk @mitraflora berdasarkan label kemasan yaitu 2-3 liter/ha (10 cc dalam 10 liter air)

penyemprotan dilakukan tigaminggu setelah di lapang dan dilanjutkan tiap dua minggu.@Mitraflora adalah pupuk organic cair dengan perbandingan komposisi Nitrogren, Phosfor (P2O5), Kalium (K2O), Kalsium (CaO), Magnesium (MgO), Sulfur (S unsure), Seng (Zn unsur), Tembaga (Cu unsur), Total Mn, Fe, Mo, dan Boron.

Persemaian benih kubis digunakan tanah halus, sekam padi dan pupuk kandang (1:1). Bedengan untuk persemaian $\pm 1,5 \mathrm{~m}^{2}$ disiapkan pada lahan yang terisolasi tetapi tidak terlalu jauh dari lahan yang akan ditanami Kubis. Benih disebar merata pada bedengan, lalu ditutup dengan daun pisang, daun kelapa selama 2-3 hari. Setelah berumur 7-8 hari, bibit Kubis dipindahkan ke dalam bedengan persemaian.Varietas yang digunakan adalah varietas yang paling sering ditanam petani adalah varietas Grand@11.Untuk areal tanam $1000 \mathrm{~m}^{2}$ diperlukan \pm 40 gram benih Grand@11. benih direndam dalam air hangat selama \pm 1 jam.

\section{HASIL DAN PEMBAHASAN}

\section{Persentase Serangan}

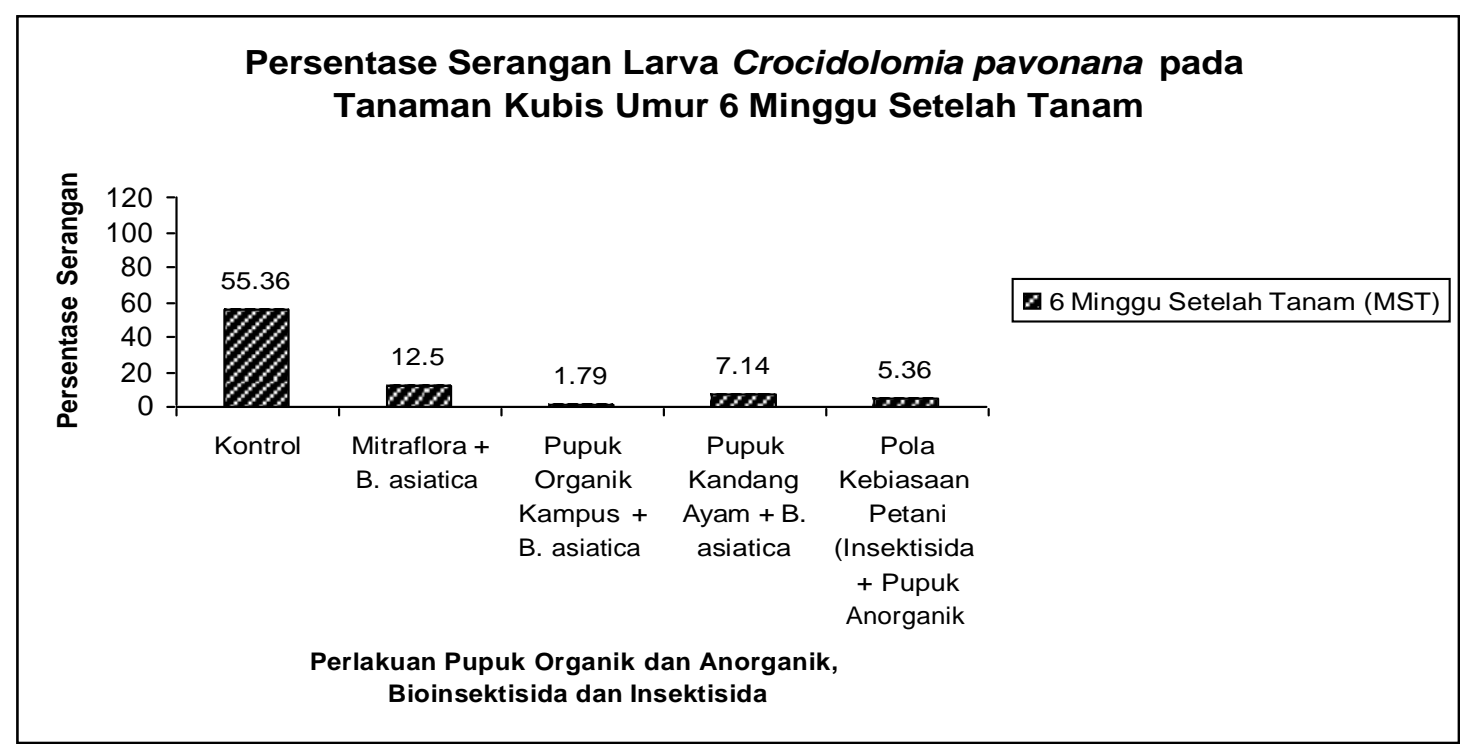

Figure 2. Percentage of $\mathrm{C}$ pavonana larvae attack on cabbage plants Age 6 Weeks After Planting.

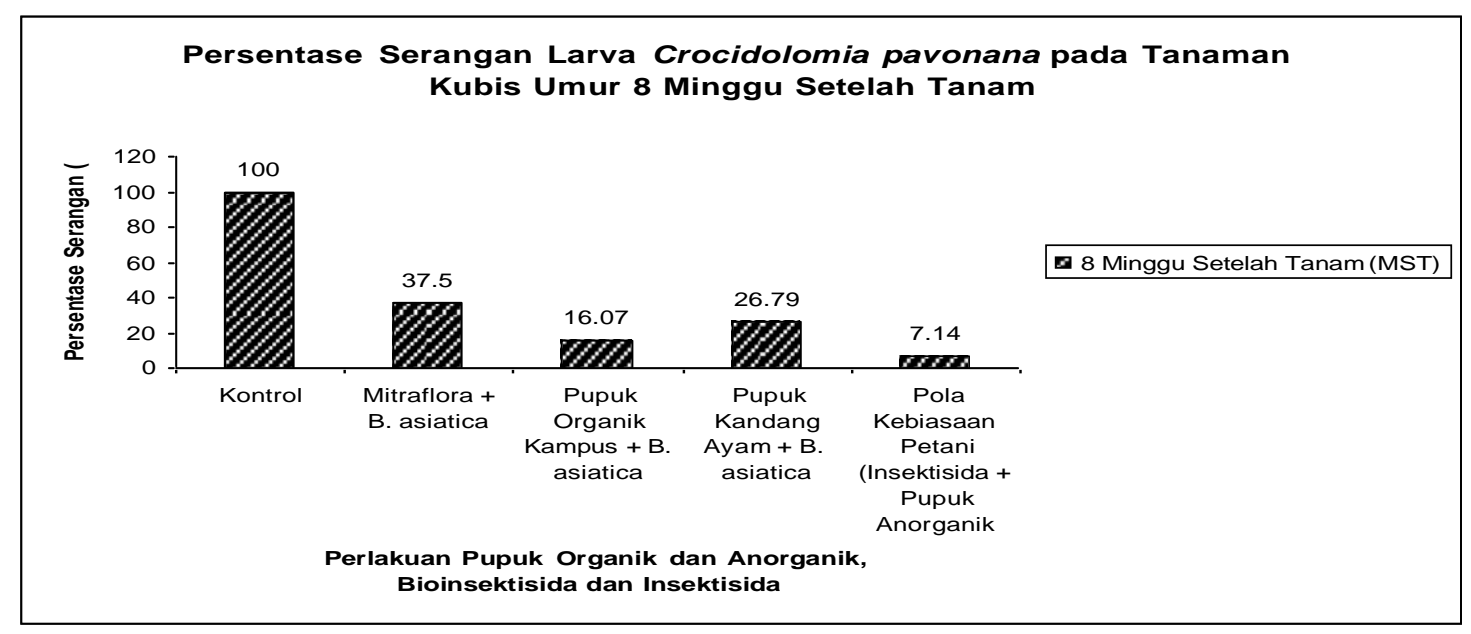

Figure 3. Percentage of $\mathrm{C}$ pavonana larvae attack on cabbage plants Age 8 Weeks After Planting. 


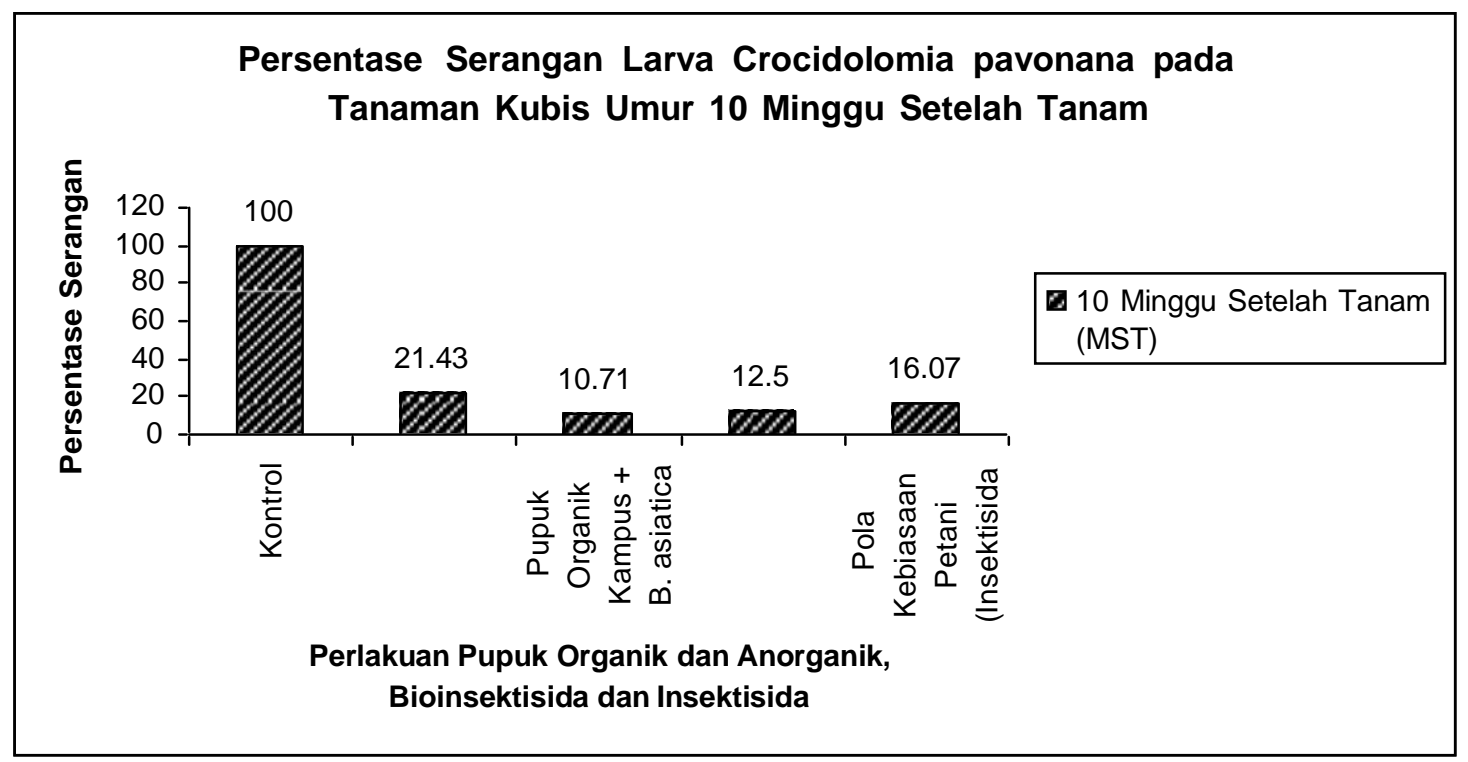

Figure 4. Percentage of $\mathrm{C}$ pavonana larvae attack on cabbage plants Age 8 Weeks After Planting.

Hasil analisis sidik ragam terhadap persentase serangan pada minggu ke 6,8 , dan 10 setelah tanam terjadi seranganhama C. pavonana pada seluruh perlakuan dengan peresentase serangan yang bervariasi. Persentase serangan pada 6 MST menunjukkan bahwa perlakuan PHT (mitraflora, pupuk organik kampus, dan pupuk kandang ayam) dan non PHT berbeda nyata terhadap kontrol, sedangkan antara perlakuan PHT (mitraflora, pupuk organik kampus, dan pupuk kandang ayam) dibandingkan dengan non PHT (pola kebiasaan petani/insektisida/pupuk anorganik) tidak berbeda nyata. Angka persentase serangan diatas menunjukkan bahwa perlakuan pupuk organik kampus $+B$. asiatica memberikan angka persentase serangan terendah 1,79\% diikuti non PHT (pola kebiasaan petani) $5,36 \%$, pupuk kandang ayam $+B$. asiatica $7,14 \%$, dan persentase serangan tertinggi pada perlakuan pupuk mitraflora + B. asiatica $12,5 \%$.

Persentase serangan pada 8 mst menunjukkan bahwa perlakuan PHT (mitraflora, pupuk organik kampus, dan pupuk kandang ayam) dan non PHT berbeda nyata terhadap kontrol, sedangkan antara perlakuan PHT (mitraflora, pupuk organik kampus, dan pupuk kandang ayam) dibandingkan dengan non PHT (pola kebiasaan petani/insektisida/pupuk anorganik) berbeda nyata. Antara perlakuan pupuk mitraflora dan pupuk kandang ayam tidak berbeda nyata tapi berbeda sangat nyata terhadap kontrol. Perlakuan pupuk organik kampus berbeda nyata terhadap pupuk mitra flora dan pupuk kandang ayam. perlakuan pupuk organik kampus berbeda sangat nyata terhadap kontrol. Perlakuan non PHT berbeda sangat nyata terhadap kontrol. Hal-hal tersebut diatas menunjukkan bahwa perlakuan pola kebiasaan petani mampu menekan serangan hama $C$. pavonana menghasilkan angka persentase serangan terendah $(7.14 \%)$, diikuti oleh pupuk organik kampus $+B$. asiatica $16.07 \%$, pupuk kandang ayam + B. asiatica $26,79 \%$, dan persentase serangan tertinggi pada perlakuan pupuk mitraflora + B. asiatica $37,5 \%$.

Persentase serangan pada 10 mst menunjukkan bahwa perlakuan PHT (mitraflora, pupuk organik kampus, dan pupuk kandang ayam) dan non PHT berbeda nyata terhadap kontrol, sedangkan antara perlakuan PHT (mitraflora, pupuk organik kampus, dan pupuk kandang ayam) dibandingkan dengan non PHT (pola kebiasaan petani/insektisida/pupuk anorganik) tidak berbeda nyata. angka persentase serangan diatas menunjukkan bahwa perlakuan pupuk organik kampus $+B$. asiatica memberikan angka persentase serangan terendah $10,71 \%$ diikuti pupuk kandang ayam + B. asiatica 12,5\%, non PHT (pola kebiasaan petani) $16,07 \%$ dan persentase serangan tertinggi pada perlakuan pupuk mitraflora $+B$. asiatica $21,43 \%$. Kandungan $N$ tanah $0,12 \%$ phosphor 21,49 , Kalium 5,79 ppm, C organik 9,47, pH tanah 6. Kandungan $\mathrm{N}$ pupuk organik dedaunan 
0,82 \%, phosphor 21,49 ppm, kalium 10,44 ppm, C-organik $9,47 \%, \mathrm{C} / \mathrm{N} 10,58$. Kandungan $\mathrm{N}$ pupuk kandang ayam 1,7 $\%$, P2O5 1,9 \%, K20 1,5\%. Kandungan $\mathrm{N}$ daun kubis varietas @Grand 11 sebesar 3,12\% dan kandungan air daun sebesar $89,69 \%$. Lokasi penelitian berada pada posisi \pm 702 mdpl. Rataan kelembaban udara $89 \%$, pH tanah 6 , rataan kelembaban tanah $22 \%$. Rataan temperatur udara $22,6^{\circ} \mathrm{C}$, rataan temperaturtanah $23^{\circ} \mathrm{C}$. Rataan jumlah hari hujan adalah 21 hari, rataan lamanya penyinaran matahari 46\%. Rataan jumlah curah hujan 166,8 milimeter.

Periode pengamatan 6, 8 dan 10 minggu setelah tanam adalah periode paling tinggi terjadi serangan hama C. pavonana. Hal ini disebabkan oleh berbagai faktor yaituadanya pola aksi tetap dan rangsang khusus senyawa metabolik sekunder terhadap serangga (Pelealu, 2004) adanya stimulasi inisiasi aktivitas makan (feeding stimulant) dalam tanaman yang memberikan isyarat untuk pengenalan makanan,adanya pendeteksian kehadiran senyawa-senyawa asing (foreign compound) yang dapat bersifat sebagai penghambat makan (feeding inhibitors) sehingga dapat memperpendek aktivitas makan atau bahkan menghentikan aktivitas makan (Tulung, 2009).

Berdasarkan hasil pengujian perlakuan PHT (pupuk organik kampus, pupuk kandang ayam, pupuk daun mitraflora) dikombinasikan dengan ekstrak bioinsektisida $B$. asiatica ternyata dapat menekan serangan hama $C$. pavonana dibanding dengan kontrol. Senyawa aktif biji $B$. asiatica yaitu senyawa turunan dari saponin yaitu $\{[\beta-D$-galaktopiranosil $(1 \rightarrow 3)$-(B-D-glukopiranosil (1 $\rightarrow 2)$-B-D-glukuronopiranosiloksi]). Rantai trisakarida merupakan gabungan dari tiga monosakarida galaktosa,glukosa dan asam glukuronat (Rumampuk, 2001) bekerja sebagai antifidan terhadap C. pavonana. Pengaruh senyawa tersebut aktivitas makan larva menjadi terhambat dan menyebabkan kurangnya asupan nutrisi yang dibutuhkan larva dalam proses pertumbuhan. Senyawa tersebutmemiliki daya bunuh yang tinggi dapat mematikan larva secara tidak langsung dengan cara menyebabkan gangguan pada sistem pengiriman sinyal perangsang makan/phagostimulant pada serangga (Schoonhoven, 1998). Senyawa ini bersifat toksik, antioviposisi, berpengaruh terhadap fekunditas, penghambatan perkembangan larva dan berpengaruh terhadap efisiensi pemanfaatan makanan larva $C$. pavonana (Dono, 2007).

Senyawa aktif biji $B$. asiatica yaitu senyawa turunan dari saponin yaitu $\{[\beta-D$-galaktopiranosil $(1 \rightarrow 3)-(\beta-D$ glukopiranosil (1 $\rightarrow 2)-\beta$-D-glukuronopiranosiloksi]) merupakan senyawa kimia rantai trisakarida gabungan dari tiga monosakarida galaktosa,glukosa dan asam glukuronat (Rumampuk, 2001) yang bersifat membunuh, mengusir dan menjerat serangga secara langsung. Senyawa antifidan hanya menghambat nafsu makan (feeding inhibition) pada serangga. Senyawa antifidan bersifat suppressant (menekan aktivitas menggigit) dan detterent (mencegah serangga terus makan) pada serangga (Mayanti, 1996 dalam Dono 2007).

Hal ini diduga diakibatkan oleh rendahnya aktivitas makan larva akibat pengaruh bahan aktif ekstrak biji $B$. asiatica. Aktivitas makan yang rendah pada larva mengakibatkan energi untuk perkembangan larva berkurang. Selain itu ada kemungkinan disebabkan oleh terganggunya fungsi organ yang menghasilkan hormone pertumbuhan. Chapman (1951) menyatakan bawa proses pergantian kulit dan metamorphosis seranggga melibatkan beberapa hormon pertumbuhan, terganggunya produksi satu jenis hormone akibat terhambatnya respirasi sel dan organ penghasil hormon, yang berdampak terhadap fungsi hormon secara keseluruhan sehingga serangga terhambat pertumbuhannya. Hal ini membuktikan bahwa ekstrak methanol biji $B$. asiatica memiliki sifat penghambat perkembangan terhadap larva C. pavonana.

Berdasarkan penelitian yang telah dilakukan oleh Dono (2007) bahwa ekstrak B. asiatica juga dapat mempengaruhi perilaku $C$. pavonana setelah memasuki fase imago yang menunjukkan perlakuan ekstrak biji $B$. asiatica dapat memperlambat kemunculan imago dan mempersingkat lama hidup imago jantan dan betina. Ekstrak B. asiatica juga dapat menunda waktu pembentukkan telur $C$. pavonana, mempengaruhi fertilitas telur (telur yang menetas) dan jumlah telur yang tersisa dalam abdomen imago. Terjadinya gangguan reproduksi imago betina $\mathrm{C}$. pavonana diakibatkan oleh senyawa tersebut.

Hasil analisis sidik ragam yang di tampilkan melalui diagram (Gambar 5.) Persentase serangan pada 6, 8 dan 10 mst terhadap pengaruh beberapa perlakuan penggunaan pupuk organik (pupuk kandang ayam, pupuk organic kampus dan pupuk organik daun mitraflora) menunjukkan bahwa persentase serangan terendah terdapat pada perlakuan pupuk organik kampus, diikuti pupuk kandang ayam dan pupuk mitraflora. 


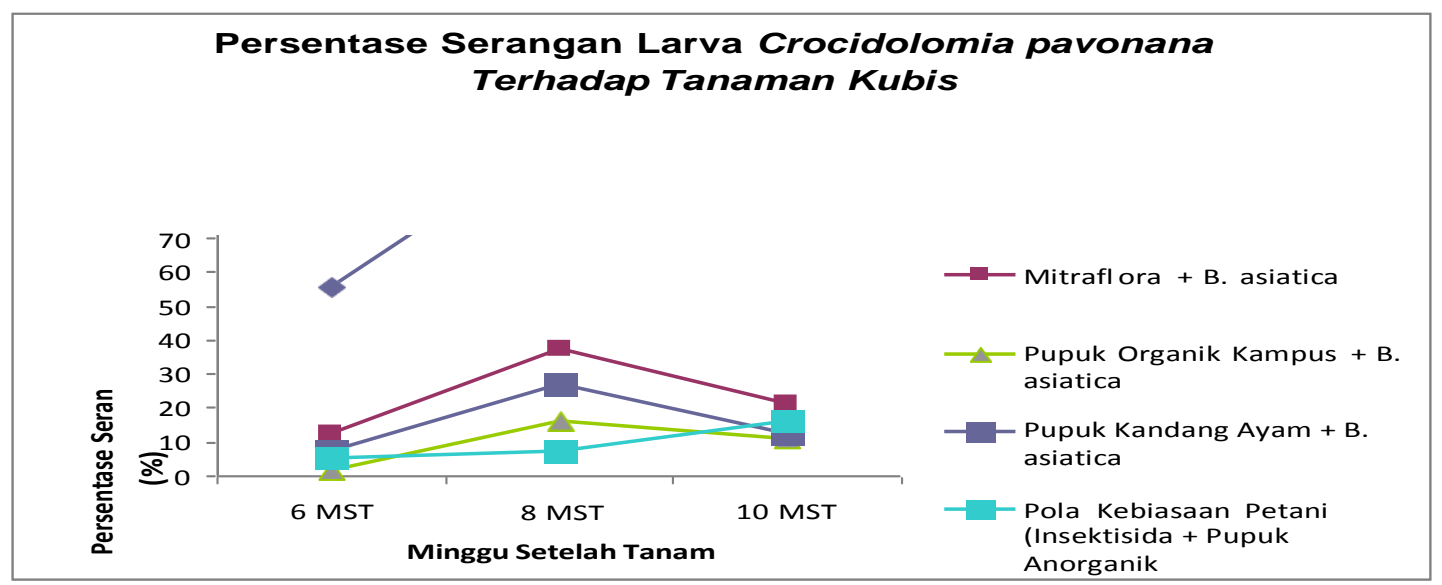

Figure 5. Percentage Curve of $C$. pavonana Larvae Attack on Several Experiments of Organic and InorganicFertilizers at Time Period (6, 8 and 10 MST)

Tingginya serangan larva pada (pupuk daun mitraflora+B. asiatica) disebabkan oleh beberapa faktor antara lain adalah pengaruh faktor lingkungan. Hasil pengukuran curah hujan rata-rata 166 milimeter dan jumlah intensitas rata-rata hari hujan yang sangat tinggi (21 hari) pada waktu penelitian, hal ini menyebabkan tercucinya pupuk dan ekstrak $B$. asiatica yang diberikan lewat daun sehingga kurang bahkan tidak efektif untuk menghambat serangan larva. Dugaan lain mengenai tingginya persentase serangan, diakibatkan karena kandungan nitrogen dan kandungan air pada sel-sel, jaringan pada organ daun tanaman sehingga memberikan daya tarik dan rangsang khusus sebagai pola aksi tetap serangan larva C. pavonana (Pelealu, 2004). Sebagian besar nitrogen tersedia dalam bentuk inorganik yang tidak dapat dimanfaatkan langsung oleh serangga (Schoonhoven et al., 1998). Hal ini menyebabkan larva C. pavonana akan mengambil cairan atau jaringan tumbuhan secara terus-menerus, mengakibatkan kerusakan krop kubis, secara langsung meningkatkan persentase serangan. Hal yang sama juga jika kandungan nitrogen dan air tinggi dalam sel-sel jaringan epidermis daun mengindikasikan turgiditas sel, pelebaran membran dan dinding sel akan meningkat. Semakin lebar membrane sel, maka keregangan membran akan semakin tinggi dan semakin tipis. Hal ini memudahkan penetrasi serangga ke jaringan tanaman.Disamping itu kemampuan dan daya cerna (chewing) larva C. pavonana akan bertambah menyebabkan kerusakan tanaman semakin tinggi pula. Hal yang sama juga terjadi pada stadium telur. Kelembaban yang optimal akan meningkatkan daya peneluran imago betina. Larva yang berkembang sempurna didalam telur keluar dengan merobek selaput vitelin, kutikula serosa, dan khorion. Suhu lingkungan merupakan salah satu faktor pendorong penetasan. Makin rendah tegangan oksigen, makin besar persentase penetasan. Kebasahan menentukan penetasan. Bila telur tidak dibasahkan maka telur dapat menetas pada tegangan oksigen yang sangat rendah. Tegangan oksigen diterima oleh pusat sensorik dikepala atau thoraks dan kepekaan maksimum seiring dengan periode aktivitas maksimum susunan syaraf pusatyangditunjukkan oleh konsentrasi asetil kholin.

Tegangan oksigen rendah mempunyai pengaruh yang berlawanan pada penetasan larva. Suhu yang cocok perlu bagi telur-telur serangga untuk menetas, ada batas ambang suhu, dibawah suhu tersebut tidak ada penetasan. Chapman (1951) melaporkan bahwa suhu bervariasi pada serangga-serangga tertentu, suhu harus lebih tinggi untuk yang mencerna kutikula serosa agar berfungsi secara efisien. Telur memerlukan kondisi aerobik untuk merangsang penetasan.

Kebanyakan serangga memaksakan keluar dari telur, pertama kali menelan cairan amnion demikian untuk meningkatkan volume telur. Kemudian memompa darah kedepan oleh konsentrasi perut sehingga kepala 
melakukan tekanan terhadap kulit telur. Serangga meningkatkan volume udara yang berdifusi melalui kulit telur atau yang masuk melalui robekan awal penetasan. Khorion dapat pecah kurang lebih tidak teratur tergantung posisi tempat yang ditekan. Khorion dapat pecah disepanjang garis-garis lemah yaitu pada garis-garis penetasan longitudinal. Penetasan serangga dibantu oleh struktur kutikula.

Kenaikkan berat pada seluruh tahapan perkembangan tetap dan kemudian merosot sedikit pada waktu pergantian kulit karena kehilangan kutikula dan kehilangan sejumlah air yang tidak dapat diganti karena serangga tersebut tidak makan. Sesudah berganti kulit dengan cepat berat meningkat diatas tingkat yang terdahulu. Kenaikkan berat ini dipengaruhi oleh penyerapan, baik melalui kutikula atau melalui saluran pencernaan. Suatu organ yang bertumbuh dengan cepat daripada bagian lain menunjukkan allometrik positif. Sedangkan pertumbuhan yang melambat disebut allometrik negatif (Chapman, 1951).

Pertumbuhan epidermis terjadi melalui suatu

\section{Produksi Kubis}

Hasil analisis sidik ragam produksi kubis pada perlakuan beberapa pupuk organik dan pola kebiasaan petani dapat dilihat pada lampiran tabel. Hasil pengamatan produksi kubis dengan periode dua kali membentuk daun setelah terkena serangan, dapat di lihat pada gambar 6 .

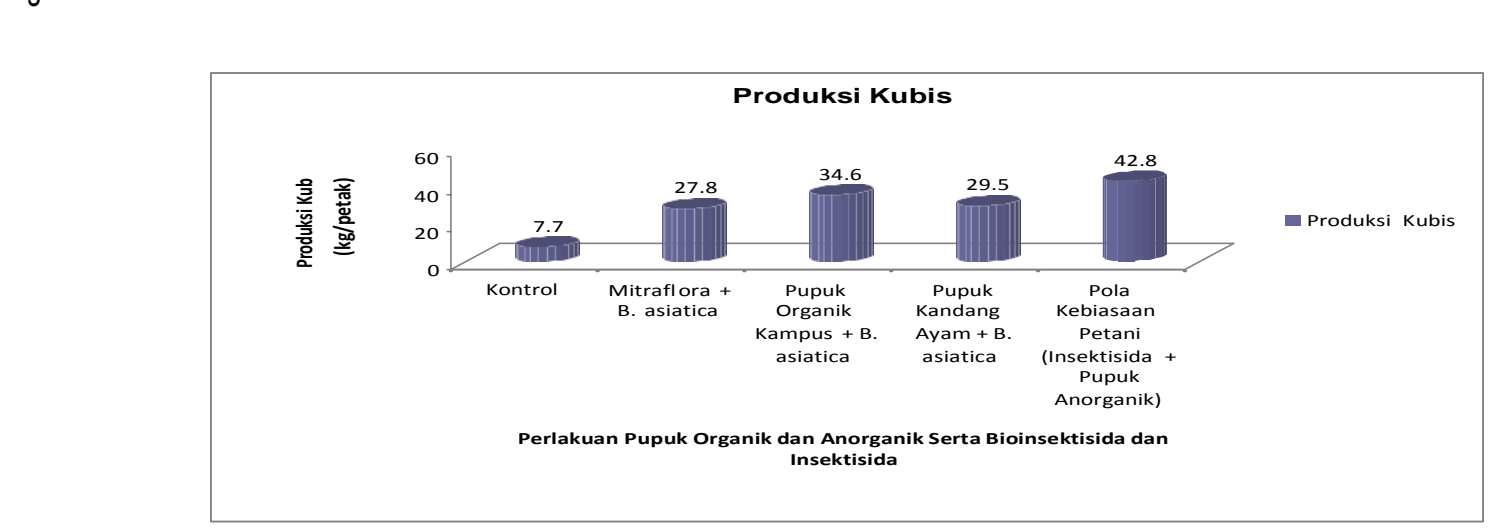

Figure 6. Stem Chart of Cabbage Production in the Organic Fertilizer Experiment, multiple cropping and farmers' habit patterns. kenaikkan dalam jumlah sel atau kenaikkan dalam ukuran sel. Jumlah sel meningkat tepat sebelum berganti kulit pada kebanyakan serangga dan ada juga setelah pergantian kulit. Kenaikkan ukuran organ dalam akibat dari suatu kenaikkan ukuran sel atau jumlah sel. Pembesaran terjadi oleh endomitosis yang terjadi pada kelenjar-kelenjar urat daging perut dan saluran malphigi. Didalam usus tengah pertumbuhan itu terjadi, sel epithel membesar, tetapi kemudian pecah selama sekresi dan masing-masing diganti oleh dua atau lebih sel-sel kecil yang berasal dari sel-sel regeneratif. Jaringan yang hancur pada waktu metamorfosis tumbuh karena pembesaran sel, sedangkan sel-sel yang tetap pada dewasa, tumbuh karena perbanyakan sel. Perkembangan saluran malphigi bervariasi. Saluran pertama timbul sebagai dorongan keluar dari proktodaeum embrio, dan saluran yang kedua yang berkembang sebagian besar dari post embrionik. Jumlah saluran bervariasi, panjang saluran meningkat pada periode inaktif perbanyakan sel, tetapi lebih disebabkan karena kenaikkan dalam ukuran sel dan di susun kembali (Chapman, 1951). 
Berdasarkan pengujian kontras ortogonal terdapat perbedaan yang nyata dalam rataan hasil produksi kubis diantara perlakuan penggunaan pupuk organik, pola kebiasaan petani dan kontrol. Terdapat perbedaan yang nyata dalam rataan hasil produksi kubis diantara perlakuan penggunaan pupuk organik dan pola kebiasaan petani. Terdapat perbedaan yang nyata dalam rataan hasil produksi kubis diantara perlakuan penggunaan pupuk organik yang diberi ekstrak Barringtonia asiatica.

Hasil pengukuran bobot kubis tertinggi dihasilkan oleh perlakuan pola kebiasaan petani yaitu 42,8 kg/petak, dikuti oleh perlakuan pupuk organik 'kampus' dengan angka produksi $34,6 \mathrm{~kg} / \mathrm{petak}$, perlakuan pupuk kandang ayam 29,5 kg/petak, perlakuan pupuk mitraflora $27,8 \mathrm{~kg} /$ petak dan terendah pada control 7,7 kg/petak. Berdasarkan hasil analisa kandungan $\mathrm{N}$ tanah $0,12 \%, \mathrm{~N}$ pupuk organic 'kampus' 0,82\% dan kandungan $\mathrm{N}$ pupuk kandang ayam $0,82 \%$. Penelitian sebelumnya yang dilakukan oleh Pelealu, (2004) terhadap lima varietas kubis menyatakan bahwa kandungan $\mathrm{N}$ daun kubis varietas@Grand 11 sebesar 3,12\% dengan kandungan air daunsebesar 89,69\%. Hal ini menunjukkan bahwa kandungan nitrogen pada areal penelitian tanaman kubis berada pada kondisi $\mathrm{N}$ yang sangat rendah.

Hasil penelitian menunjukkan bahwa produksi tertinggi dihasilkan oleh pola kebiasaan petani (anorganik) yaitu 42,8 kg/petak, diikuti oleh perlakuan pupuk organik 'kampus' dengan angka produksi $34,6 \mathrm{~kg} / \mathrm{petak}$, perlakuan pupuk kandang ayam 29,5 kg/petak, perlakuan pupuk mitraflora $27,8 \mathrm{~kg} /$ petak dan terendah pada kontrol 7,7 $\mathrm{kg} /$ petak. Hal ini menguatkan teori-teori sebelumnya bahwa pupuk anorganik lebih tersedia dan cepat diserap oleh tanaman sedangkan pupuk organik daun dan pupuk kandang ayam lebih lambat diserap tanaman, karena pupuk organik yang berasal dari sisa-sisa tanaman dan kotoran hewan memerlukan waktu untuk penguraian lanjutan dalam tanah, pemutusan ikatan-ikatan unsur yang terikat kuat dalam senyawa, kapasitas tukar kation, dan $\mathrm{N}$ yang dikonsumsi oleh mikrobia tanah, $\mathrm{N}$ yang mengalami volatilisasi, $\mathrm{N}$ yang mengalami pencucian (leaching). Pola pemberian pupuk melalui daun (@mitraflora) tidak terlalu efektif pada penelitian ini. Hal ini disebabkan karna penelitian dilaksanakan bertepatan dengan periode bulan basah yaitu curah hujan, lama hujan yang tinggi menyebabkan pupuk yang diberikan banyak yang tercuci.
Kandungan $\mathrm{N}$ total tanah yang rendah pada lokasi penelitian yaitu $0,12 \%$, kandungan $\mathrm{N}$ pupuk organik kampus $0,82 \%$ dan kandungan $\mathrm{N}$ pupuk kandang ayam 1,7\%, pH tanah 6. Rendahnya kandungan $\mathrm{N}$ total tanah diasumsikan bahwa konsentrasi pemberian pupuk akan lebih banyak diserap tanaman dan digunakan sebagian oleh mikroorganime tanah. Sel-sel tanaman yang kelebihan nitrogen menyebabkan turgiditas sel meningkat, keregangan membran sel meningkat, maka akan memudahkan penetrasi $C$. pavonana. Hal-hal ini akan sangat berpengaruh terhadap produksi kubis dan persentase serangan larva $C$. pavonana. Beberapa faktor yang menyebabkan yaitu pada saat aplikasi terjadi musim kemarau, akhir periode aplikasi yaitu awal bulan November, mulai musim penghujan terjadi pertumbuhan kubis secara normal dan mulai terjadi pembentukan krop. Dalam waktu singkat larva-larva $\mathrm{C}$. pavonana mulai menyerang tanaman kubis yang sedang dalam periode pembentukan krop. Dengan demikian maka tanaman yang telah terserang larva C. pavonana tidak dapat membentuk krop lagi. Akibat banyaknya larva yang masih hidup sehingga terjadi serangan pada titik tumbuh mengakibatkan terhentinya pembentukan krop tanaman kubis.

\section{KESIMPULAN DAN SARAN}

\section{Kesimpulan}

1. Persentase serangan tertinggi pada $6 \mathrm{mst}$ terdapat pada perlakuan pupuk mitraflora $+B$. asiatica $12,5 \%$ pupuk kandang ayam + B. asiatica $7,14 \%$, pola kebiasaan petani $5,36 \%$, dan perlakuan pupuk organik kampus +

B. asiatica $1,79 \%$.

2. Persentase serangan tertinggi pada $8 \mathrm{mst}$ terdapat pada perlakuan pupuk mitraflora $+B$. asiatica $37,5 \%$, pupuk kandang ayam + B. asiatica $26,79 \%$, pupuk organik kampus + B. asiatica $16.07 \%$, pola kebiasaan petani $7.14 \%$.

3. Persentase serangan tertinggi pada $10 \mathrm{mst}$ terdapat pada perlakuan pupuk mitraflora $+B$. asiatica $21,43 \%$, pola kebiasaan petanipupuk kandang ayam + B. asiatica $12,5 \%$, pupuk organik kampus + B. asiatica10,71\%.

4. Produksi kubis tertinggi dihasilkan oleh pola kebiasaan petaniyaitu 42,8 kg/petak, diikuti oleh perlakuan pupuk organik 'kampus' + B. asiatica dengan angka produksi 34,6 $\mathrm{kg} /$ petak, perlakuan pupuk kandang ayam + B. asiatica 29,5 $\mathrm{kg} /$ petak, perlakuan pupuk mitraflora + B. asiatica 27,8 $\mathrm{kg} / \mathrm{petak}$.

\section{Saran}

Perlu dilakukan analisis kandungan $\mathrm{N}$ total pada seluruh tanaman uji. 


\section{DAFTAR PUSTAKA}

Anonim, 1995. Pengendalian Hama Terpadu Pada Tanaman Kubis. Kerjasama Balai Penelitian Tanaman Sayuran dengan Program Nasional Pengendalian Hama Terpadu Departemen Pertanian. Hal 75-83.

Chapman, F. IR. 1971. Struktur dan Fungsi Alat Tubuh

Serangga. Terjemahan Soetiyono Partoesoejono. American Elsevier Publishing Company, Inc. New York. Vol. I. 617 Hal.

Dono, D, Prijono, dan S. Manuwoto. 2007. Penghambatan Enkapsulasi Pradewasa Parasitoid Eriborus argenteopilosus (Cameron) Oleh Larva Crocidolomia pavonana (F.) Menggunakan Rokaglamida.

http://www.bionatura. unpad.ac.id/index.php?opt ion=com_content\&view=article\&id=233. akses tanggal 10 maret 2011.

Mattjik, A. dan Sumertajaya, I. 2002. Perancangan Percobaan. Edisi II IPB Press 287 hal.

Ooi. P, 1998. Farmer Participation in IPM Action Research. Paper Presented at the International Conference on IPM-Theory and Practice, Developing Sustainable Agriculture, Guangzhou, China June 15-20. http://www.regional.org.au. Di akses tanggal 11 Februari 2011.

Pelealu, J. 2004. Ketertarikan Oviposisi Crocidolomia binotalis Zell (Lepidoptera: Pyralidae) Terhadap Berbagai Kultivar Brassica oleraceae var. capitata. Disertasi. Program Pascasariana Institut Teknologi Bandung (ITB). 104 Halaman.

Pelealu, J. 2009. Pembangunan Pertanian Organik. Pidato

IImiah. Fakultas Pertanian Unsrat. 18 Februari 2009.

Rumampuk, R.J. 2001. Elusidasi Struktur Saponin Dari Biji

Barringtonia asiatica (L.) Kurz. Disertasi, Universitas Padjadjaran, Bandung.

Sembel, D.T dan J. Rimbing, 1991. Inventarisasi musuhmusuh alami pada tanaman pangan di Sulawesi Utara. J. Res. \& dev. Sam Ratulangi University : II(4): 7 16.

Sembel, D. T., 1989. Pengendalian Hayati - Hama-hama Serangga Tropis Dan Gulma. Penerbit Andi Yogyakarta. 281 hal.
Schoonhoven, L. Jermy, T, dan Van Loon, 1998. Insect And Plant Biology. Published by Chapman \& Hall. London. First Edition. 408 pp.

Tulung, M. 2009. Pemanfaatan Insektisida Botanis Untuk Mengendalikan Hama Tanaman Sayuran. Pidato IImiah. Fakultas Pertanian Unsrat. 8 Desember 2009.

Wanta, N., Maramis. R., dan Rimbing. J., 1994. Perbandingan Antara Pelepasan D. semiclausum Hornstm (Hymenoptera: Ichneumonidae) Dengan Penyemprotan Bacillus thuringiensis Berl. Untuk Pengendalian Hama Plutella xylostella Lin. (Lepidoptera: Yponomeutidae) Pada Tanaman Kubis diMinahasa. Eugenia X(15):1-10. 